\title{
PENGARUH PEMBELAJARAN IPA MODEL PROBLEM BASED LEARNING BERBANTUAN DIAGRAM VEE TERHADAP KEMAMPUAN BERPIKIR KRITIS PESERTA DIDIK SMP
}

\author{
Afni Nirwana ${ }^{1} \&$ Insih Wilujeng ${ }^{2}$ \\ ${ }^{1,2}$ Pendidikan IPA, Universitas Negeri Yogyakarta, Indonesia \\ Corresponding author email: afni.nirwana2016@student.uny.ac.id
}

\begin{abstract}
Submit: 20 Maret 2021
Accepted: 22 April 2021

Publish: 30 April 2021

Abstrak:

Penelitian ini bertujuan untuk menganalisis pengaruh dan mengatahui besarnya pengaruh pada penerapan pembelajaran IPA dengan problem based learning berbantuan diagram Vee terhadap kemampuan berpikir kritis peserta didik. Penelitian ini merupakan penelitian quasi experiment dengan desain nonequivalent control group. Populasi dalam penelitian ini adalah siswa kelas VII SMP Negeri 7 Yogyakarta. Sampel dalam penelitian ini diambil dengan teknik cluster random sampling atau pengambilan secara acak sehingga didapatkan kelas VII D sebagai kelas eksperimen dan kelas VII E sebagai kelas kontrol. Instrumen yang digunakan dalam penelitians ini adalah lembar keterlaksanaan pembelajaran, lembar observasi berpikir kritis, dan lembar soal pretest-posttest keterampilan berpikir kritis. Analisis data dalam penelitian ini menggunakan Perhitungan N-Gain, Uji Independent Sample T-Test, dan Perhitungan Effect Size. Hasil penelitian menunjukkan adanya pengaruh yang signifikan pada model problem based learning terhadap keterampilan berpikir kritis dengan besar pengaruh sebesar 1,91 atau dalam kategori tinggi.
\end{abstract}

Kata kunci: model problem based learning, diagram vee, berpikir kritis

\begin{abstract}
This aims of this research are to analyze the influence and determine the magnitude of the effect on the application of science learning with problem based learning aided by the vee diagram on students critical thinking skills. This research is a quasi-experimental study with a nonequivalent control group design. The population in this research were $7^{\text {th }}$ grade students of 7 Yogyakarta Junior High School. The sample in this research was drawn randomly so that D class was obtained as the experimental class and E class as the control class. The instruments that are used in this research were learning execution form, critical thinking observation form, and pretest-posttest question sheets of critical thinking skills. Data analysis in this reasearch used the $N$-Gain calculation, Independent Sample T-Test, and Effect Size. The results showed a significant influence on the model of problem based learning on critical thinking skills with a large effect is 1.91 or in the high category.
\end{abstract}

Keywords: problem based learning, diagram vee, critical thinking 


\section{Physics and Science Education Journal (PSEJ) Volume 1 Nomor 1, April 2021}

\section{Pendahuluan}

IPA atau sains merupakan suatu cara berpikir untuk memahami suatu gejala alam dan sebagai batang tubuh keilmuan yang diperoleh dari suatu penyelidikan (Supriyadi, 2009:3). Pembelajaran IPA menjadi sarana bagi peserta didik untuk mempelajari diri sendiri dan alam sekitar, serta diperlukan untuk memenuhi kebutuhan manusia melalui pemecahan masalah yang muncul dalam kehidupan sehari-hari. Menurut Widowati (2009:84), tantangan masa depan menuntut pembelajaran harusnya lebih mengembangkan keterampilan berpikir kreatif dan kritis (high order of thinking). Higher order thinking atau yang disingkat "HOT" merupakan salah satu komponen dalam isu kecerdasan abad ke-21 (The issue of 21 st century literacy). Hal tersebut menunjukkan bahwa memasuki abad ke-21, dunia sedang membutuhkan sumber daya manusia yang berkualitas unggul yang dapat menguasai 4 keterampilan yaitu communication, colaboration, creative, dan critical thinking.

Menurut hasil observasi, pembelajaran IPA kelas VII di SMP Negeri 7 Yogyakarta pada bulan Februari dan Agustus 2019 menunjukkan bahwa keaktifan peserta didik belum merata, ada beberapa peserta didik yang aktif bertanya dan kritis namun ada pula beberapa peserta didik yang pasif serta ada pula peserta didik yang aktif namun keluar dari materi pokok bahasan. Pembelajaran juga belum maksimal mengarahkan peserta didik untuk menjawab pertanyaan-pertanyaan yang membutuhkan kemampuan berpikir tingkat tinggi (HOTS).

Ada beberapa model, strategi, maupun metode pembelajaran yang dapat melatih keterampilan berpikir kritis peserta didik diantaranya yaitu model PBL (Problem Based Learning), model PjBL (Project Based Learning), strategi Make A Match, dan strategi True or False, dan metode Cooperative Learning tipe Jigsaw. Akan tetapi pada saat dilakukan observasi pembelajaran di SMP N 7 Yogyakarta pada bulan Februari dan Juli hingga Agustus, model dan strategi pembelajaran tersebut belum maksimal diterapkan di sekolah.

Pentingnya keterampilan berpikir kritis menyebabkan banyak penelitian tentang berpikir kritis tersebut dengan berbagai metode yang berbeda. Pertama, penelitian oleh Yunin, Nurun Naviah dan Wardan Suyanto, tahun 2014, dengan hasil penerapan model PBL dapat meningkatkan keterampilan berpikir kritis peserta didik dalam pembelajaran yaitu sebesar $24,2 \%$. Kedua, penelitian oleh Ichsani Putri, Mutia, tahun 2017, dengan hasil penerapan model PBL dalam pembelajaran berbantuan video berpengaruh terhadap keterampilan berpikir kritis peserta didik dengan nilai effect size 0,91 dalam kriteria besar.

Sains (IPA) adalah tentang mempelajari fenomena alam dan pemecahan permasalahan yang timbul dalam kehidupan sehari-hari. Proses pemecahan masalah dalam melatih keterampilan berpikir kritis tersebut perlu diajarkan kepada peserta didik agar peserta didik terbiasa untuk selalu berpikir dan mencari solusi. Model pembelajaran yang dapat melatih peserta didik untuk pemecahan masalah yaitu Problem Based Learning. Problem Based Learning (PBL) merupakan pembelajaran yang membebaskan peserta didik untuk memilih penelitiannya sendiri sehingga memungkinkan mereka untuk mengaitkannya dengan fenomena nyata dan membangun pemahaman dengan konsep yang mereka dapatkan dari fenomena tersebut. Untuk memperjelas arah dan tujuan dalam proses pembelajaran, maka dalam penyusunan instrumen pembelajaran (LKPD) ditambahkan dengan diagram Vee yang sesuai dengan tahap Problem Based Learning. Menurut Norak dan Gowin (2002:5), diagram Vee merupakan suatu diagram yang membantu peserta didik untuk mengetahui struktur dari suatu ilmu/pengetahuan dan proses ilmu/pengetahuan tersebut dibangun. Berdasarkan uraian di atas perlu dilakukan penelitian yang bertujuan untuk meningkatkan keterampilan berpikir kritis peserta didik yaitu "Pengaruh Penerapan Pembelajaran IPA dengan Model Problem Based Learning Berbantuan Diagram Vee Terhadap Kemampuan Berpikir Kritis Peserta Didik".

\section{Metode Penelitian}

Jenis penelitian ini adalah eksperimen semu atau quasy experiment dengan desain nonequivalent control group. Penelitian ini menguji pengaruh yang diberikan variabel bebas (model PBL berbantuan diagram vee) terhadap variabel terikat (kemampuan berpikir kritis).

\section{Waktu dan Tempat Penelitian}

Penelitian ini dilaksanakan pada bulan Februari sampai dengan Maret 2020 bertempat di SMP Negeri 7 Yogyakarta. 


\section{Populasi dan Sampel Penelitian}

Populasi dalam penelitian ini adalah peserta didik kelas VII SMP Negeri 7 Yogyakarta tahun ajaran 2019/2020 yang terbagi menjadi 6 kelas, yaitu kelas VII A, VII B, VII C, VII D, VII E dan VII F. Sampel diambil dengan cluster random sampling atau sampel diambil dengan pengambilan acak. Sampel yang terpilih sebagai kelas eksperimen adalah kelas VII D dan kelas kontrol adalah kelas VII E.

\section{Prosedur}

Desain pada penelitian ini adalah nonequivalent control group.

Tabel 1. Desain Penelitian

\begin{tabular}{cccc}
\hline Kelompok & Pretest & Perlakuan & Postest \\
\hline Eksperimen & $\mathrm{O}_{1}$ & $\mathrm{X}_{\mathrm{PBL}}$ & $\mathrm{O}_{2}$ \\
Kontrol & $\mathrm{O}_{1}$ & $\mathrm{X}_{\text {kontrol }}$ & $\mathrm{O}_{2}$ \\
\hline
\end{tabular}

Keterangan:

$\mathrm{O}_{1} \quad$ : Pretest kemampuan berpikir kritis

$\mathrm{X}_{\mathrm{PBL}} \quad$ : Pembelajaran dengan model problem based learning

$\mathrm{X}_{\mathrm{kontrol}} \quad$ : Pembelajaran dengan model cooperative learning

$\mathrm{O}_{2} \quad$ : Posttest untuk mengetahui kemampuan berpikir kritis

\section{Intrumen dan Teknik Pengumpulan Data}

Instrumen dalam penelitian ini meliputi lembar observasi keterlaksanaan pembelajaran, lembar observasi berpikir kritis, dan soal pretest posttest. Lembar observasi diisi oleh observer yang mengamati jalannya proses pembelajaran. Soal pretest posttest digunakan untuk mengumpulkan data kemampuan berpikir kritis peserta didik. Soal berjumlah 8 soal uraian. Teknik pengumpulan data pada penelitian ini yakni menggunakan tes dan non tes. Teknik tes menggunakan soal pretest posttest. Adapun non tes menggunakan lembar observasi keterlaksanaan pembelajaran dan lembar observasi berpikir kritis.

\section{Teknik Analisis Data}

Teknik analisis data pada penelitian ini meliputi uji prasyarat hipotesis dan uji hipotesis. Uji prasyarat hipotesis terdiri dari uji normalitas dan uji homogenitas. Uji hipotesis menggunakan menggunakan uji Independent Sample T Test. Analisis hasil peningkatan kemampuan berpikir kritis dilakukan dengan menghitung hasil pretest dan posttest tiap peserta didik dan rata-rata skor peserta didik pada tiap kelasnya, dengan menghitung gain menggunakan rumus:

$$
N \text { Gain }=\frac{\text { nilai posttest-nilai pretest }}{\text { skor maksimal-nilai pretest }}
$$

Kriteria penilaian hasil perhitungan gain ternormalisasi seperti pada Tabel 3.

Tabel 2. Kategori Skor Gain

\begin{tabular}{cc}
\hline Besarnya gain $(\mathrm{g})$ & Interpretasi \\
\hline $\mathrm{g} \geq 0,7$ & Tinggi \\
$0,3<\mathrm{g} \leq 0,7$ & Sedang \\
$\mathrm{g}<0,3$ & Rendah \\
\hline
\end{tabular}

(Sumber: Sundayana, 2015) 
Nilai besar pengaruh model pembelajaran PBL berbantuan diagram vee dapat dicari menggunakan effect size. Menurut Cohen, dkk (2007:521) menghitung effect size menggunakan rumus:

$$
d=\frac{X e-X k}{S g a b}
$$

Dengan

$$
\mathrm{S} \text { gab }=\sqrt{\frac{(\mathrm{n} 1-1) S_{1}^{2}+(\mathrm{n} 2-1) S_{2}^{2}}{n 1+n 2-2}}
$$

Keterangan,

$d=$ Cohen's effect size (besar pengaruh dalam persen)

$\mathrm{Xe}=$ rata-rata kelas eksperimen

$X k=$ rata-rata kelas control

$S g a b=$ standar deviasi gabungan

Interpretasi hasil perhitungan effect size dikategorikan sebagai berikut.

Tabel 3. Kriteria Effect Size Cohen's

\begin{tabular}{cc}
\hline Besar d & Interpretasi \\
\hline $0-0,20$ & Efek lemah \\
$0,21-0,50$ & Efek sedang \\
$0,51-1,00$ & Efek cukup/layak \\
$>1,00$ & Efek kuat \\
\hline
\end{tabular}

Sumber : Cohen dan Morrison (2011)

Persentase keterlaksanaan pembelajaran ditentukan dengan menggunakan persamaan berikut.

$$
\% \text { Skor }=\frac{\text { nilai yang diperoleh }}{\text { jumlah seluruh nilai }} \times 100 \%
$$

Keterlaksanaan pembelajaran IPA diimplementasikan ke dalam beberapa kriteria yang ditunjukkan pada Tabel 4.

Tabel 4. Persentase Keterlaksanaan Pembelajaran

\begin{tabular}{cc}
\hline Persentase $(\%)$ & Kategori \\
\hline $80<\mathrm{x} \leq 100$ & Sangat baik \\
$60<\mathrm{x} \leq 80$ & Baik \\
$40<\mathrm{x} \leq 60$ & Cukup \\
$20<\mathrm{x} \leq 40$ & Kurang \\
$0<\mathrm{x} \leq 20$ & Sangat kurang \\
\hline
\end{tabular}

Sumber : Eko Putro Widoyoko (2009)

Analisis lembar observasi berpikir kritis menggunakan rumus:

$$
\% \text { Skor }=\frac{\text { nilai yang diperoleh }}{\text { jumlah seluruh nilai }} \times 100 \%
$$

\section{Hasil Penelitian dan Pembahasan}

Data hasil dari penelitian ini berupa nilai pretest dan posttest serta skor pada lembar observasi berpikir kritis. Hasil tes kemampuan berpikir kritis peserta didik dapat dilihat pada Gambar 1. Hasil pretest dan posttest peserta didik kemudian diuji prasyarat untuk mengetahui dapat atau tidaknya dilakukan uji hipotesis. Uji prasyarat meliputi uji normalitas dan uji homogenitas. Berdasarkan hasil pengujian, 
didapatkan bahwa nilai signifikansi lebih besar dari 0,025 atau data yang diperoleh terdistribusi normal dan bersifat homogen.

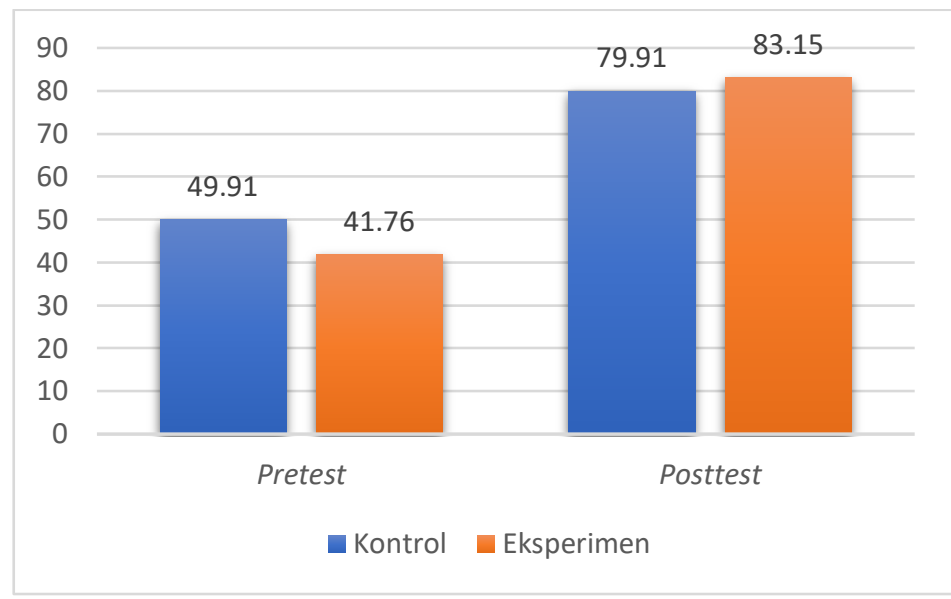

Gambar 1. Diagram Hasil Tes Kemampuan Berpikir Kritis

Analisis uji hipotesis dilakukan menggunakan uji Independent Sample T Test. Sebelum pengujian hipotesis, maka dilakukan perhitungan nilai $\mathrm{N}$-Gain untuk mengetahui hasil peningkatan kemampuan berpikir kritis peserta didik pada kelas eksperimen maupun kelas kontrol. Skor N-Gain yang diperoleh pada kelas kontrol bernilai 0,50 sedangkan pada kelas eksperimen bernilai 0,71. Hal ini menunjukkan bahwa peningkatan kemampuan berpikir kritis pada kelas eksperimen atau kelas dengan pembelajaran model problem based learning lebih tinggi daripada kelas kontrol yang pembelajaran menggunakan model cooperative learning. Selanjutnya setelah mengetahui nilai N-Gain dilakukan uji hipotesis atau uji beda menggunakan Independent Sample T Test dimana memperoleh hasil nilai Sig. (2-tailed) sebesar 0,000 atau kurang dari $1 / 2 \alpha(0,05)$ sehingga dapat diketahui bahwa terdapat perbedaan kemampuan berpikir kritis yang signifikan antara kelas eksperimen dan kelas kontrol. Adanya perbedaan tersebut menunjukkan adanya pengaruh model pembelajaran problem based learning terhadap kemampuan bepikir kritis. Pernyataan ini didukung oleh hasil penelitian Putri (2017) yang menyatakan bahwa penerapan model PBL dalam pembelajaran berpengaruh terhadap berpikir kritis peserta didik.

Setelah diketahui bahwa ada pengaruh dalam penerapan model PBL berbantuan diagram vee terhadap kemampuan berpikir kritis peserta didik, maka untuk mengetahui besar pengaruhnya dilakukan perhitungan effect size. Berdasarkan perhitungan yang telah dilakukan dengan efek d Cohen's diperoleh besar pengaruh sebesar 1,91 atau dalam kategori tinggi. Indikator kemampuan berpikir kritis pada penelitian ini meliputi interpretasi, analisis, inferensi, evaluasi dan eksplanasi. Data kenaikan kemampuan berpikir kritis pada posttest masing-masing indikator disajikan dalam diagram batang pada Gambar 2 .

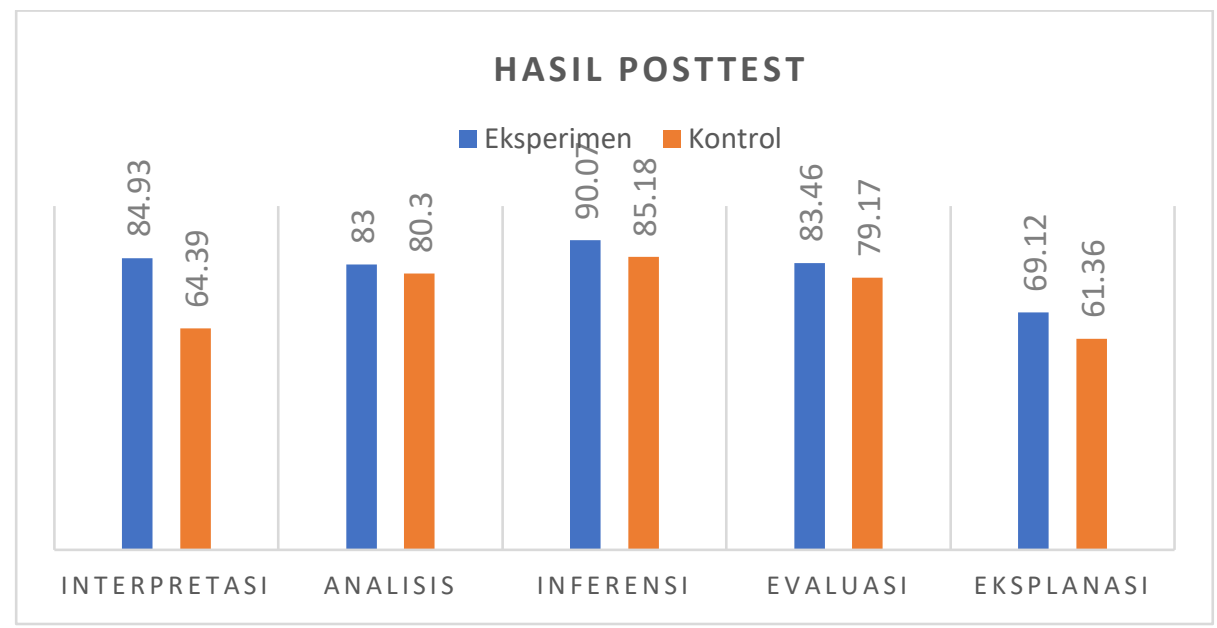

Gambar 2. Diagram Nilai Posttest Masing-Masing Indikator 
Indikator yang mengalami kenaikan paling tinggi adalah interpretasi. Interpretasi dalam pembelajaran adalah dengan menafsirkan suatu kasus dalam artikel/video yang kemudian disampaikan dalam bentuk rumusan masalah. Pada kelas eksperimen memperoleh nilai tinggi pada indikator interpretasi karena kelas tersebut menggunakan pembelajaran problem based learning berbantuan diagram vee dimana peserta didik selalu diminta untuk menafsirkan suatu artikel dalam LKPD dan membuat rumusan masalah yang kegiatan ini tidak terjadi pada pembelajaran dengan model cooperative learning pendekatan saintifik atau pada kelas kontrol. Kemudian indikator yang mengalami kenaikan paling rendah adalah analisis, hal ini dikarenakan dalam pembelajaran dengan model problem based learning maupun pembelajaran dengan model cooperative learning pendekatan saintifik selalu ada kegiatan menganalisis sehingga peserta didik dalam kelas eksperimen maupun kelas kontrol dapat melakukan kegiatan analisis dengan baik.

Penelitian juga mengukur kemampuan berpikir kritis peserta didik menggunakan lembar observasi dengan cara memberikan skor pada rentang 1 sampai 4 pada kolom sesuai dengan pengamatan pada aspek interpretasi, analisis, inferensi, evaluasi dan eksplanasi. Hasil observasi kemampuan berpikir kritis disajikan dalam Gambar 3.

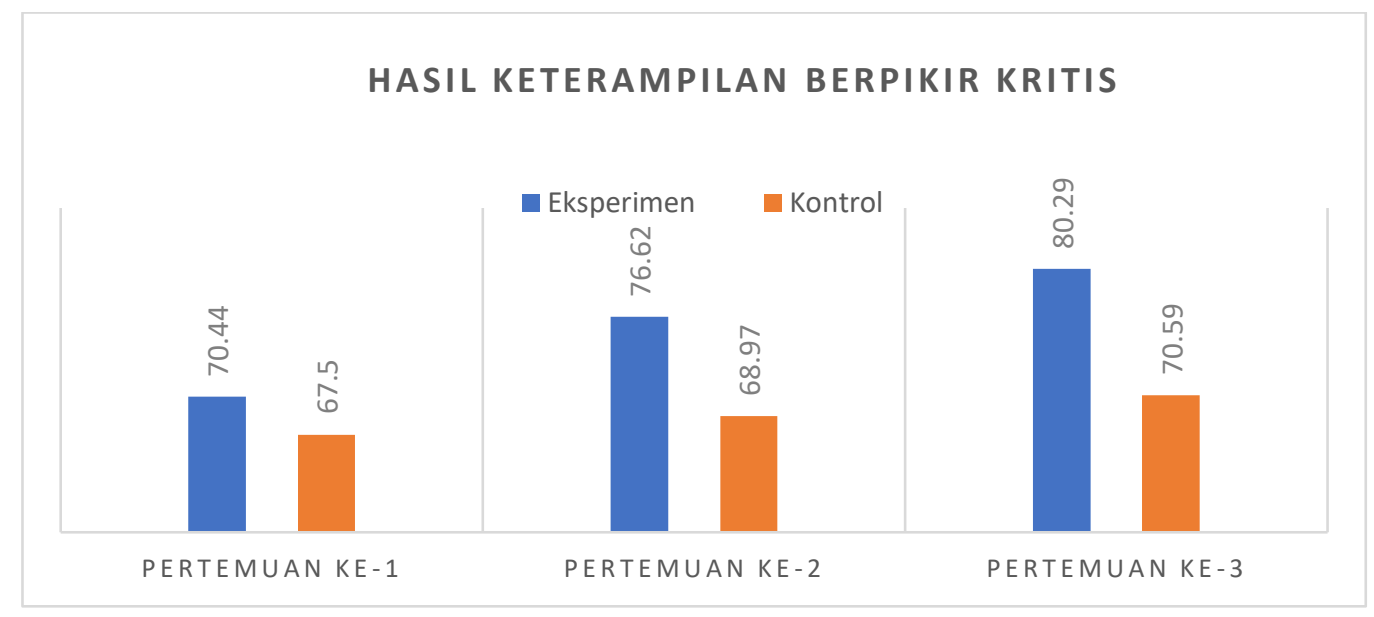

Gambar 3. Data Hasil Rata-Rata Kemampuan Berpikir Kritis Peserta Didik Setiap Pertemuan

Berdasarkan Gambar 3 diketahui bahwa terjadi peningkatan secara signifikan pada kelas eksperimen. Model pembelajaran problem based learning learning berbantuan diagram vee dapat berpengaruh terhadap kemampuan berpikir kritis peserta didik karena model pembelajaran problem based learning memfasilitasi peserta didik dengan sebuah permasalahan sebagai konteks bagi peserta didik untuk belajar tentang cara berpikir kritis dan keterampilan pemecahan masalah, serta untuk memperoleh pengetahuan dan konsep yang dari materi pelajaran. Hal ini sesuai dengan pendapat Daryanto (2014: 29) yang menyatakan bahwa Problem Based Learning (PBL) atau pembelajaran berbasis masalah merupakan suatu model pembelajaran yang menantang peserta didik untuk bekerja secara berkelompok untuk mencari solusi dari permasalahan dunia nyata. Selain itu didukung oleh hasil penelitian dari Nafiah \& Suyanto (2014) yang menyatakan bahwa penerapan model problem based learning dalam pembelajaran dapat meningkatkan keterampilan berpikir kritis peserta didik dengan peningkatan sebesar $24,2 \%$. Hasil penelitian dari Fatimah (2015) juga menyatakan bahwa model pembelajaran problem based learning dengan pendekatan JAS (Jelajah Alam Sekitar) dapat meningkatkan keterampilan berpikir kritis peserta didik sebesar 74,35\% dan hasil penelitian dari Kurniawati (2015) menyatakan bahwa media pembelajaran berbantuan komputer berbasis PBL efektif digunakan untuk meningkatkan kemampuan berpikir kritis peserta didik.

Penerapan model problem based learning berbantuan diagram vee mendorong peserta didik untuk mengembangkan metode ilmiah dalam proses penyelidikan atau pemecahan masalah. Hal ini sesuai dengan pendapat Trianto (2007: 67) yang menyatakan bahwa model pembelajaran berbasis masalah (problem based learning) merupakan suatu model pembelajaran yang didasarkan pada banyaknya permasalahan yang membutuhkan penyelidikan autentik yakni penyelidikan yang membutuhkan penyelesaian yang nyata. Hasil penelitian dari Dzikrina (2017) juga menerangkan bahwa pembelajaran IPA melalui model Problem Based Learning dapat meningkatkan berpikir kritis peserta didik SMP. 
Pemilihan materi yang mengandung permasalahan juga sangat penting sehingga dapat disesuaikan dengan media pembelajaran yang akan digunakan. Materi yang digunakan adalah materi pencemaran lingkungan. Materi pencemaran lingkungan merupakan materi faktual yang didasarkan pada aktivitas dan permasalahan-permasalahan yang muncul dalam kehidupan sehari-hari. Hal ini diharapkan peserta didik dapat belajar berdasarkan pengalaman dan pengamatan masalah lingkungan dalam kehidupan. Dalam penelitian Insih Wilujeng (2019) menyatakan, "In the world of education, a teacher can play a role in environmental sustainability by fostering the students' views on environmental issues around them. Contextual science learning will make students have a higher environmental stance. The young generation who have the right attitude of environmental literacy will concern the sustainability of the environment and it is hoped to significantly help the world in the future, in terms of natural resources security."

Hal tersebut menjelaskan bahwa dalam dunia pendidikan, guru dapat membimbing peserta didik untuk belajar secara langsung ke suatu lingkungan untuk mengamati isu atau masalah lingkungan yang ada di sekitar mereka. Pembelajaran sains secara kontekstual ke lingkungan akan membuat peserta didik memiliki sikap peduli lingkungan yang lebih tinggi. Generasi muda yang memiliki sikap peduli lingkungan yang baik akan prihatin dan bertanggung jawab terhadap keberlanjutan lingkungan dan akan membantu memperbaiki lingkungan untuk masa depan. Dalam penelitian tersebut membuktikan bahwa pembelajaran IPA yang menggunakan pendekatan EESD (Education For Environmental Sustainable Development) dapat meningkatkan literasi lingkungan peserta didik.

Diagram vee sangat membantu dalam penerapan model problem based learning karena di dalam diagram tersebut termuat metode-metode untuk mendorong kemampuan menalar dan berpikir kritis peserta didik. Pendapat ini didukung oleh pendapat Chamizo (2011) yang menyatakan bahwa diagram vee adalah sebuah pendekatan untuk mengekspos ketidaktahuan peserta didik dari suatu topik atau area belajar. Diagram vee juga membantu peserta didik untuk mengorganisasi ide atau informasi serta membantu peserta didik untuk menggapai materi yang belum diketahui.

Diagram vee dalam LKPD IPA dalam penelitian ini merupakan prosedur atau langkah-langkah peserta didik untuk menyelesaikan permasalahan yang dikaji. Setiap langkah dalam diagram vee diberikan penomoran untuk mempermudah peserta didik dalam menyelesaikan masing-masing langkah. Dalam diagram tersebut terdapat dua sisi yang saling berhubungan yaitu sisi konseptual dan sisi metodologis. Kedua sisi tersebut dihubungkan oleh sebuah objek atau permasalahan yang akan dikaji sehingga dari sinilah langkah awal peserta didik untuk dapat menganalisis permasalahan dan berpikir kritis dalam pemecahan masalah. Hasil penelitian dari Laelasari tahun 2016 yang menyatakan bahwa penerapan diagram vee dalam pembelajaran berbasis masalah lebih meningkatkan kemampuan berpikir kritis peserta didik dibandingkan pada pembelajaran berbasis masalah tanpa diagram vee. Implementasi diagram vee akan membentuk suatu pola yang potensial untuk bisa diterapkan dalam pembelajaran berbasis masalah. Hal tersebut dikarenakan terdapat beberapa kemiripan antara langkah dalam diagram vee dengan sintaks model Problem Based Learning.

\section{Simpulan}

Berdasarkan hasil penelitian maka dapat disimpulkan bahwa penerapan model problem based learning berbantuan diagram vee memberikan pengaruh yang signifikan terhadap kemampuan berpikir kritis peserta didik dengan besar pengaruh senilai 1,91 atau dalam kategori tinggi dan penerapan model problem based learning berbantuan diagram vee dalam pembelajaran IPA merupakan salah satu model pembelajaran yang dapat mengembangkan kemampuan berpikir kritis peserta didik. Berdasarkan penelitian yang telah dilakukan, terdapat beberapa saran yaitu (1) guru disarankan untuk menerapkan model problem based learning dalam pembelajaran IPA dengan pemilihan materi yang sesuai yaitu materi yang memiliki unsur permasalahan yang dapat diselesaikan dengan penelitian atau percobaan; (2) guru sebaiknya membuat perencanaan langkah-langkah kegiatan dan mengatur waktu pembelajaran yang tepat agar setiap sintaks dalam model problem based learning dapat terlaksana secara maksimal.

\section{Referensi}

Arikunto. (2006). Dasar-Dasar Evaluasi Pendidikan. Jakarta : PT Bumi Aksara. 
Chamizo, J.A. (2011). Heuristik Diagrams as a Tool to Teach History of Science. Jurnal Science \& Education 21, 745-762.

Cohen, L., Manion, L., \& Morrison, K. (2011). Research Methods in Education $\left(6^{\text {th ed }}\right)$. London, New York: Routllege Falmer.

Daryanto. (2014). Pendekatan Pembelajaran Saintifik Kurikulum 2013. Yogyakarta: Gava Media.

Dzikriya, A., Wilujeng, I., \& Hastuti, P.W. (2017). Peningkatan Kemampuan Berpikir Kritis dalam Pembelajaran IPA Melalui Model Problem Based Learning (PBL). Jurnal Pendidikan Ilmu Penegtahuan Alam 6 (8).

Fatimah, S. (2015). Critical Thinking Skills and Creativity Enhancement in $7^{\text {th }}$ Student Grade Through PBL Model and JAS Approach. Jurnal Pendidikan IPA Indonesia 4 (2), 149-157.

Kurniawati, Atik \& Suryadarma, I.G.P. (2015). Penyusunan Media Pembelajaran Berbantuan Komputer Untuk PBL dan Keefektifannya Terhadap CTS Peserta Didik SMA. Jurnal Inovasi Pendidikan IPA 1 (1), 57-64.

Laelasari. Iseu. (2016). Penerapan Diagram Vee dalam Pembelajaran Berbasis Masalah untuk Meningkatkan Kemampuan Berpikir Kritis dan Metakognisi pada Materi Sistem Respirasi. Diakses dari repository.upi.edu.

Nafiah, Y. \& Suyanto, W. (2014). Penerapan Model Problem Based Learning untuk Meningkatkan Keterampilan Berpikir Kritis dan Hasil Belajar Siswa. Jurnal Pendidikan Vokasi 4 (1).

Norak, J.D,. \& Gowin, D.B. (2002). Learning How to Learn. Combrige : Cambrige University Press.

Putri, M.I. (2017). Pengaruh Model Problem Based Learning Berbantuan Video Terhadap Keterampilan Berpikir Kritis Pada Siswa SMP. Yogyakarta: FMIPA UNY.

Sundayana, Rostiana. (2015). Statistika Penelitian Pendidikan. Bandung: Alfabeta.

Supriyadi. (2009). IPA Dasar. Yogyakarta: FMIPA UNY.

Trianto. (2007). Model-Model Pembelajaran Inovatif Berorientasi Konstruktivistik. Surabaya: Prestasi Pustaka Publisher.

White, H. (2007). Problem-based learning in introductory science across disciplines. http://www.udel.edu/chem/white/finalrpt.html.

Widowati, Asri. (Mei 2009). Pengembangan Critical Thinking Melalui Penerapan Model PBL (Problem Based Learning) Dalam Pembelajaran Sains. Makalah disajikan dalam Seminar Nasional Penelitian, Pendidikan dan Penerapan MIPA, di Universitas Negeri Yogyakarta.

Widoyoko, E.P. (2009). Evaluasi Program Pembelajaran. Yogyakarta: Pustaka Pelajar.

Wilujeng, I., Dwandaru, W.S., \& Rauf, R.A. (2019). The Effectiveness of Education for Environmental Sustainable Development to Enhance Environmental Literacy in Science Education: A Case Study of Hydropowe. Jurnal Pendidikan IPA Indonesia 8 (4), 521-528. 